\title{
Quality is Never an Accident: A Survey on the Total Quality-Management Practices amongst Selected Higher Education Institutions in the Philippines
}

\author{
Glenn S. Cabacang, DBA \\ De La Salle - College of St. Benilde / Polytechnic University of the Philippines - \\ College of Business Administration Graduate Studies / Ascendens Asia \\ https://orcid.org/0000-0002-9963-3128
}

\begin{abstract}
Total Quality Management (TQM) is regarded as a gauge of university management, in order to maintain global standards. This study examined Total Quality-Management (TQM) implementation and the practices of higher education institutions in the Philippines. It utilized a cross-sectional survey-study design to 347 respondents recruited from the total population of 3847 administrators and academic members of nine selected institutions in the Philippines. The measure of TQM adoption and practices was extracted from several sources of previous TQM researches. This study was done for six months. The analyzation and interpretation of the data were done by using descriptive and inferential statistics. The results indicated that participating Filipino HEIs had a high degree of adoption on top-management commitment, Teaching and Learning Delivery Modes, campus amenities, system and process management, customer satisfaction, and linkages. In contrast, the HEIs have a modest degree of acceptance in strategic planning and Data Management. The test of differences indicated that strong confirmation to top management commitment and strategic planning as indicators of TQM is significantly more evident in private-type HEIs; and it was placed at the university level, when compared to those of the provincial and national HEIs. The findings provide some practical implications to further enhance Filipino HEIs in the advent of the Fourth Industrial Revolution.
\end{abstract}

Keywords: Total Quality Management; TQM; Higher Education Institutions; practices; Philippines; survey; High-Quality Education

\section{Introduction}

Changes may happen exceptionally and rapidly in the current corporate world. Throughout the framework of global competitiveness in the economic environment, companies have to adapt, in order to cope with the quick changes correctly. The colleges and higher education institutions have three major responsibilities in the education sector: instruction, research, and community 
service (Ellahi et al., 2019). The Total Quality Management (TQM) of university education provides a clear commitment that should mobilize institutions, improve employee engagement, or enhance nearly any system that it includes (Aminbeidokhti et al., 2016, Psomas \& Antony, 2017, Sahney, 2016). With this urgent problem, higher education institutions of the globe place their priorities and plans on their framework and shape TQM practices (Khan et al., 2019, Manatos et al., 2017, Mendes \& Dias, 2018, Arcinas, 2021, Sabarre et al., 2021, Charernnit et al., 2021, De Souza et al., 2021).

Total quality-management (TQM) is regarded as a new organizational philosophy that depends on a lot of modern views and theories, based on a mix of conventional managerial methods, creative initiatives, and advanced technical knowledge, in order to increase performance, and also to achieve continuous improvement (Li et al., 2018, Psomas \& Anthony, 2017, Magulod, 2019, Nuncio et al, 2020, Rocha \& Arcinas, 2020, Do et al., 2017, Fundin et al., 2018, Tolentino \& Arcinas, 2020, Arcinas et al., 2020). TQM impacts educational institutions, and they are expected to boost returns, in order to become productive, profitable, and client-oriented, in order to improve their competitiveness (Grudzień \& Hamrol, 2016).

TQM is a procedure that can assist in this educational progress. It is a theory of continuous development that may provide various skills and analytical resources that should satisfy the needs and the expectations of any higher education institution (Shams \& Belyaeva, 2019, Tasopoulou \& Tsiotras, 2017, De Vincenzi et al., 2018, Magulod, 2017). Within the new global economy, which is marked by accelerated technological transition, intensive knowledge transfers and increasing competition through the elimination of trade barriers and commerce, the universities around the world are compelled to gradually evolve as enterprises that are guided by the competitive necessity of market mechanisms, despite the common issues and problems that they all have to face (Baptista et al., 2019, Brint, 2019, Costandi et al., 2019, Taylor et al., 2019).

In this era of transition, it has become essential for a university to enhance its ability to adapt to its environment through ground-breaking approaches and professional academic leadership. The literature on the TQM analysis of higher education is based mainly on psychology or on the behavioural sciences, and less on administration and management as a whole (Carvalho, 2011, Dias, 2015, Pennock et al., 2015). Performance issues in HEIs include: instruction, study, facilities, and basic strategies (Cardoso et al., 2016, Stensaker et al., 2011). Studies on quality management have affirmed a positive relationship between qualitymanagement practices and competitive advantage (Brem et al., 2016, Delery \& Roumpi, 2017, Elshaer \& Augustyn, 2016, O’Neill et al., 2016, Ross, 2017).

The quality management of higher education institutions is reflected in the following indicators, namely top-management commitment, strategic planning, customer satisfaction, data management, system and operational management, infrastructure, the teaching and learning-delivery systems, and on the linkages (Abbas, 2020, Abu Amuna et al., 2017, Arda et al., 2019, Bromiley \& Rau, 2016, 
Deshpande, 2020, Mahdi et al., 2019, Ross, 2017, Ruben, 2018, Saiz-Alvarez, 2020, Shams \& Belyaeva, 2019, Tatoglu et al., 2020, Yu et al., 2020).

As to the research context, Filipino higher education has undergone a drastic increase. Depicting the fast growth of the higher education system, quality management is currently becoming a key focus in many countries throughout the last decade (Liu \& Liu, 2017). With this background, several attempts have been made to establish efficient quality-management systems for university education. It is, therefore, essential to analyse such quality-assurance systems that are being applied among the Philippine universities. Although there is a plethora of studies relating to TQM, most of the research projects have been preliminary, theoretical, and conceptual, whether concentrating on adapting the strategies of management of tertiary institutions, or by incorporating the expertise from other countries (Aljuhani, 2019, Alzafari \& Kratzer, 2019, Cudney et al., 2020, Kumar et al., 2018, Murmura et al., 2016, Nurcahyo et al., 2019, Olcay \& Bulu, 2017, Wen et al., 2018).

Some of the TQM studies were found to be relating to business firms, such as foods and non-food manufacturing and production (Cho et al., 2017, Ding et al., 2019, Florkowski \& Jiang, 2017, Kong et al., 2016, Liao et al., 2018). Among the studies conducted that relate to TQM among universities is that of Song (2018), who identified the strategies and the impacts of a world-class research university. It was reported that linking and institutional policies on international students are those TQM factors required to achieved world-class Filipino universities. At the same time, Yan et al. (2019) considered the TQM synergy and collaboration among universities and enterprises. Meanwhile, Wang (2019) recommended using UK and Filipino quality-assurance systems in one university, as the factor of TQM.

Hou et al. (2018) attempted to develop an internal quality-assurance mechanism for universities in Malaysia, Singapore, the Philippines, and South Korea. They reported that external quality-assurance approaches should comply with international certification, validation, and global credentialing.

Previously, Filipino institutions concentrated mainly on quality assurance by implementing the whole idea of quality management. Hence, this study investigates the quality-management systems of Filipino higher education institutions. In this study, the gap in the literature has been addressed by performing a cross-sectional survey on adopting the eight TQM criteria among the selected institutions in the Philippines. This study gives administrators and faculty members the much-needed practical consequences they require, in order to extend their knowledge on the ongoing improvement of the TQM ideas. The selected higher education institutions would also gain from the inputs into this analysis, for their strategy and policy creation and execution of the development plan concerned, together with a constant improvement of the TQM concept.

\section{Objectives of the Study}

This study has generally aimed to ascertain Total Quality Management (TQM) among the selected universities in the Philippines. Accordingly, it specifically aims to answer the following research questions: (1) What is the level of TQM 
adoption of the Select Filipino Universities in the eight areas? (2) Is there a significant difference in TQM adoption, when grouped, according to the types of the selected HEIs?

\section{The Method}

\section{The Research Design}

The study is a descriptive cross-sectional survey research project, which investigates the level of adoption and the practices of the HEIs in the TQM areas. The self-reported cross-sectional survey design was used to collect the data from the respondents. The use of a cross-sectional survey has been a form of observational study, which examines the information from a community or from a sample group at a specific point in time (Bryman, 2006, Coughlan et al., 2007, Nardi, 2018).

\section{The Research Participants, Sampling Procedure, and Ethical Considerations}

The respondents of the survey comprise 347 samples from the total population of 3847 administrators and the academic members of nine selected institutions in the Philippines. A list of institutions was acquired from the data repository of the Commission on Higher Education. To allow more accessible access to the respondents, the poll was performed via an online survey. In addition, the security elements of the online study were added, such as providing a security code to responding institutions, in order to avoid anybody who could just fill out the survey.

The major respondents of the survey were the administrators and the faculty members. The inquiry started in June 2019; and it finished in August 2019. Two stages of the survey were utilized, and a total of 347 questionnaires were gathered. Since these might not necessarily be significant, the representation of the respondents was appropriate and extremely inclusive, as a result of the use of a multi-stage stratified-sampling technique, in which the stages were based on the findings of Breslow and Weiss (2018). Raosoft was used to calculate the sampling size for a $347-$ item collection with a 5\% margin of error, a 95\% degree of confidence, and a $50 \%$ response distribution.

The online software from Raosoft was accessed via the following URL: http://www.raosoft.com/samplesize.html. Raosoft's sampling package offers power values for a given sample size and alpha level, thereby allowing for the evasion of Type I and Type II mistakes (Cuenca-Amigo \& Makua, 2017, Wilson, 2016).

Table 1 presents the frequency and the percentage representation of the samples. As regards the types of HEIs, the majority of the completed online questionnaires were sourced from provincial HEIs (37\%), followed by National HEIs (32\%), and the private HEIs $(30 \%)$. This investigation was guided by the following ethical issues. Initially, the university's ethics committee approved the data privacy and the informed consent forms, and, in order to maintain the respondents' and institution's confidentiality, no names were mentioned. 
Table 1. Distribution of Samples

\begin{tabular}{clcc}
\hline Variables & \multicolumn{1}{c}{ Category } & $\begin{array}{c}\text { Frequency } \\
\text { Distribution } \\
(\mathbf{n}=\mathbf{3 4 7})\end{array}$ & $\begin{array}{c}\text { Percentage } \\
\text { Distribution }\end{array}$ \\
\hline Types of HEIs & National & 112 & 32 \\
& Provincial & 130 & 37 \\
& Private & 105 & 30 \\
\hline
\end{tabular}

\section{The Research Instruments}

\section{The measure of TQM Adoption and practices}

The standard of TQM adoption and that of the methodologies was lifted from diverse sources of previous TQM research. It focuses on the eight aspects of TQM (Yaakub \& Samsudin, 2019). The 72 elements were adapted from previous studies noting, however, that TQM has different meanings. The eight areas were namely: the top-management's commitment (Vouzas \& Psychogios, 2007), which consisted of items 1-9, strategic planning (Hu et al., 2018), for details 10-18, customer satisfaction (Bouranta et al., 2017) for details 19-27, data management (Yusr et al., 2017) items 28-36, system and process management (Suarez et al., 2016) contains the item numbers 45-54, teaching and learning (Martínez-Caro et al., 2015) for the items 55-63, and Benchmark (Sweis et al., 2016) for the questions 64-72. The instrument has a calculated Cronbach-alpha coefficient of 0.83 .

\section{The Procedure}

Generally, this study was done for six months. The procedure of obtaining study data lasted for three months. Before the formal gathering time, the authority's consent and authorization to perform the study was requested of the Commission on Higher Education. The second week began with the issuance of a notice to proceed with the research. After acquiring the proper authorization, the researcher identified the respondents by using the inclusive criteria stated in this study. Then, the design and the creation of a questionnaire, which will be uploaded online, were done. The researcher properly followed the ethical research considerations. After gathering the students' replies, they were coded and submitted to data cleaning and statistical analysis for one month. Finally, the findings' analysis, interpretation, and report-writing were done for another month.

\section{The Data Analysis}

To evaluate the study's quantitative findings, basic descriptive statistics, such as frequency count, percentage distribution, weighted mean, and standard deviation were employed, in order to understand correctly the sample background of the respondents. The descriptive statistical results of the TQM were attained, by using the five-point Likert scale. These were interpreted with the scale range and description: Strongly Agree/ Very High a (4.20-5.00), Agree/ High b (3.40-4.19), Undecided/ Moderate c (2.60-3.39), Disagree/ Low d (1.80-2.59), strongly Disagree/ Very Low e (1.00-1.79). Moreover, inferential statistics, such as the oneway Analysis of Variance (ANOVA) were used to examine the differences in the adoption of the practice of TQM. The Post Hoc Tukey Honest Significant 
Difference (HSD) test was used to assess whether the significant differences in the respondents' TQM adoption and practices were taken into consideration; since this would tell exactly where the differences are to be found (Abdi \& Williams, 2010).

\section{The Results}

Research Question 1. What is the level of TQM adoption of the Select Filipino Universities in the eight areas?

Table 2 shows the level of adoption of the eight TQM areas identified in the study, and that the select HEIs have a high level of TQM adoption, as demonstrated by the grand mean of 3.96. It is also worth noting that they routinely receive a high degree of approval from top-management's dedication $(\mathrm{M}=4.12, \mathrm{SD}=.966)$, Teaching and Learning Delivery Modes $(\mathrm{M}=4.12, \mathrm{SD}=0.75)$, campus facilities $(\mathrm{M}=4.24, \mathrm{SD}=0.865)$, system and process management $(\mathrm{M}=4.12, \mathrm{SD}=0.894)$, customer satisfaction $(\mathrm{M}=3.48, \mathrm{SD}=0.959)$, and linkages $(\mathrm{M}=4.10, \mathrm{SD}=0.456)$. In contrast, the HEIs have a moderate level of adoption on strategic planning $(\mathrm{M}=3.37, \mathrm{SD}=0.867)$ and Data Management $(\mathrm{M}=3.36, \mathrm{SD}=0.910)$.

Table 2. Level of Adoption on the Different Areas of TQM

\begin{tabular}{|c|c|c|c|c|}
\hline Areas & $\begin{array}{c}\text { Mean } \\
(\mathrm{n}=347)\end{array}$ & SD & $\begin{array}{l}\text { Descriptive } \\
\text { Interpretation }\end{array}$ & $\begin{array}{l}\text { Level of } \\
\text { Adoption }\end{array}$ \\
\hline Management & 4.12 & 0.966 & Agree & High \\
\hline Commitment & & & & \\
\hline Strategic Planning & 3.37 & 0.867 & Undecided & Moderate \\
\hline $\begin{array}{l}\text { Customer Satisfaction } \\
\text { Focus }\end{array}$ & 3.48 & 0.959 & Agree & High \\
\hline Data Management & 3.36 & 0.910 & Undecided & Moderate \\
\hline $\begin{array}{l}\text { System and Processes } \\
\text { Management }\end{array}$ & 4.12 & 0.894 & Agree & High \\
\hline Campus Facilities & 4.24 & 0.865 & Agree & High \\
\hline $\begin{array}{l}\text { Teaching and Learning } \\
\text { Delivery Modalities }\end{array}$ & 4.12 & 0.754 & Agree & High \\
\hline Benchmarking & 4.10 & 0.456 & Agree & High \\
\hline Grand Mean & 3.86 & & Agree & High \\
\hline
\end{tabular}

Legend: Strongly Agree/ Very High ${ }^{a}$ (4.20-5.00), Agree/ High ${ }^{b}$ (3.40-4.19), Undecided/Moderate ${ }^{c}$ (2.60-3.39), Disagree/ Lowd (1.80-2.59), strongly Disagree/ Very Low e (1.00-1.79)

The high level of the assessment provided to top management's commitment revealed that the Filipino HEIs had positive leadership aspects, which comprise the administration in respect of quality-management principles. This implies that the upper management of the different HEIs have active leadership and participation in developing and maintaining consumer attention, defining and providing ideas, principles, objectives consistently, as well as high expectations, and a governance structure that would encourage the consistency of the results.

They are capable of highlighting the fact that the internal systems and organizational practices influence students and staff, as well as the population and the creation of connections with business, stakeholders, and the public in general. 
Marin et al. (2019), in their study on the framework of quality management, reported that management and leadership are predictors of TQM. Previous studies have reported similar findings that quality assurance includes the four primary parameters of quality assurance: human competence, process \& method competence, conceptual and experiential competence (Chen et al., 2020, ClayWilliams et al., 2020, Johansson \& Wallo, 2019, Teoman \& Ulengin, 2018, Tiwari \& Kumar Sharma, 2017). Consequently, management leadership is an important factor of TQM.

Meanwhile, university facilities have been scored high by the respondents, demonstrating thereby that the HEIs have high esteem in the prevision of convenience among students and other stakeholders, notably the students. The conclusion suggests that the HEIs must see to it that they place their priorities on the growth of school services and education, as well as on the learning facilities. The academic institution is provided with a range of services, including a library, a lecture theatre, a cafeteria, a student hostel, and many more. Similarly, campus amenities are the infrastructure supplied by the university that may bring comfort and convenience to university students and to the staff. This category outlines the amenities provided and delivered by the firms to their internal or external clientele.

Studies have indicated that these facilities are regarded as the indications of TQM among colleges, which is a factor that influences customers loyalty and service quality (Kasiri et al., 2017, Meesala \& Paul, 2018, Nyadzayo \& Khajehzadeh, 2016. Successively, the Filipino HEIs also ranked their system and process management as the TQM indications being high, thereby suggesting that they can recognise the possible features of systems integration, such as students' curriculum design, instructional implementation, program, and business operations. They have a high estimation of how the critical process is intended to be creative, efficiently regulated, and to be continuously enhanced. This specifies students' performance and improvement via the utilization of essential processes and metrics.

This topic outlines the cycle of institutional help and tactical preparation for economic management and planning, in order to increase operational efficiency. Previous studies have confirmed that institutional processes and systems are the bridging factors towards TQM (Ferdousi et al., 2018, Helleno, 2017, Suarez et al., 2016).

In a similar way, high appraisal has been provided to the customers' satisfaction focus by the HEIs. This area indicates that the HEIs may establish how the universities recognise the expectations, requirements, wants, and preferences of learners, partners, and the industrial emphasis. This includes establishing the multiple metrics of success, as well as how these goals may be met. The HEIs can also adopt various indications of progress, which would be created on the basis of the teaching-quality polls, school meetings and discussion meetings, business needs or feedback surveys, and the assessment of learning and teaching efficacy. It further examines how higher education develops relationships with the 
students and with the stakeholders; and it identifies the essential elements that attract talent and provide them to the advantage of students and stakeholders.

Previous studies also showed that there is a structural relationship between TQM practices and customer satisfaction (Chen et al., 2017, Lee et al., 2010, MorenoLuzon et al., 2013, Ooi et al., 2013, Phan et al., 2011).

Moreover, the teaching and learning modes were evaluated as being high by the HEI respondents, demonstrating the great importance of instruction, as a collaborative activity of the students and the instructors. They created a high conviction that learning is a circle of interaction among teachers and learners; so that the knowledge and awareness mastering process could occur. The provision of teaching and learning is an activity that involves the exchange of information between teachers and undergraduates, which is performed elsewhere. This indicator describes the systems of learning and teaching done inside an institution. The range of learning modes should help the school. Studies suggest that teachers and students are the advocates of TQM, where quality standards start in the classroom (Baig et al., 2015, Bunglowala \& Asthana, 2016, Chen et al., 2017, Rampa, 2010, Shroff, 2019).

Benchmarking, as a TQM indicator, has been evaluated highly by the HEIs, demonstrating thereby that they are capable of coping with the dynamic changes effectively. In this event, the educational establishment compares its facilities and activities with those of their commercial colleagues, in order to increase the level of efficiency via benchmarking. To meet the market's needs constantly, higher education institutions have to evaluate their programs and methods by assessing their major counterparts in the same sector, as well as in any other sectors that employ the same technique. Benchmarking has been regarded as an essential factor of TQM among HEIs in the world (Al-Zoubi, 2012, Kern Pipan et al., 2014, Levy \& Ronco, 2012, Rolstadås, 2012, Sweis et al., 2015).

Furthermore, the HEIs also exhibited a modest level of adoption of strategic planning and data management, as the markers of TQM. The conclusion shows that the HIEs cannot reach the best practice of effective strategic management and data management, as indicators of TQM. Strategic planning outlines how the institution sets out its future orientation and establishes its strategic goals, in order to guide and increase the quality of all organizations. This category further indicates how well the organization transforms strategic objectives into risk assessments; and how the institution works out a series of strategic goals and plans, at all stages of the institution. Effective strategic management improves the implementation of TQM among HIEs (Bromiley \& Rau, 2014, Calvo-Mora et al., 2014, Chen et al., 2017, Moldovan, 2012, Rahimnia \& Kargozar, 2016).

The moderate degree of data-management practice of the HEIs, demonstrates that they have a satisfactory technique of knowledge management, as an element of TQM. Data-management elements and expertise should define the execution and the efficiency of data usage, and the necessary resources needed to enhance the overall task-related success and excellence. Furthermore, it should assure the 
security and the availability of both the key information needed for day-to-day general administration. This should, therefore, concentrate on evaluating the facts and the information, as well as reacting effectively and efficiently to the circumstances (Calvo-Mora et al., 2015, Chang et al., 2011, Corredor \& Goñi, 2011, Mehralian et al., 2013, Roldán et al., 2012, Valmohammadi \& Roshanzamir, 2015).

In general, the study showed that the participating Filipino HEIs have a high level of adoption on top management's commitment, Teaching and Learning Delivery Modes, campus facilities, system and process management, customer satisfaction, and linkages. In contrast, the HEIs have only a moderate level of adoption in strategic planning and in Data Management.

Research Question 2. Is there a significant difference in TQM adoption, when grouped according to the types and the levels of the select HEIs?

Table 3 shows the test of the differences in the practice and adoption of TQM when grouped, according to the types and levels of the HEIs. When taken to the types of HEIs, significant differences showed in top management's commitment $\left(p=0.00^{* *}\right)$ and strategic planning $\left(p=0.004^{* *}\right)$. It shows that the national and private HEIs have better adoption and practices on top management's commitment and strategic planning than do the Philippines' other counterparts. Consequently, as to the levels of HEIs, strategic planning $\left(\mathrm{P}=0.000^{* * *}\right)$ and high management commitment $\left(\mathrm{p}=0.046^{*}\right)$ were seen to be significant. Consequently, this study showed a considerable difference in the level of adoption and the practices on TQM, when grouped, according to the types and standards used by the select universities.

Table 3. Test of Differences on the adoption of TQM, when grouped according to the Types and Levels of HEIs

\begin{tabular}{lcc}
\hline \multicolumn{1}{c}{ Areas } & Types & Levels \\
\hline Top Management's Commitment & $\mathbf{0 . 0 0 0}^{* *}$ & $\mathbf{0 . 0 4 6}^{*}$ \\
Strategic Planning & $\mathbf{0 . 0 0 4}^{* *}$ & $\mathbf{0 . 0 0 0}$ \\
Customer Satisfaction & $0.543 \mathrm{~ns}$ & $0.768 \mathrm{~ns}$ \\
Data Management & $0.897 \mathrm{~ns}$ & $0.765 \mathrm{~ns}$ \\
System and Processes Management & $0.123 \mathrm{~ns}$ & $0.768 \mathrm{~ns}$ \\
Campus Facilities & $0.459 \mathrm{~ns}$ & $0.476 \mathrm{~ns}$ \\
Teaching and Learning Delivery & $0.343 \mathrm{~ns}$ & $0.344 \mathrm{~ns}$ \\
Modalities & & \\
Benchmark & $0.567 \mathrm{~ns}$ & $0.176 \mathrm{~ns}$ \\
\hline
\end{tabular}

Note: ${ }^{*} p<0.05,{ }^{* *} p<0.01,{ }^{* * *} p<0.00$

$n s=$ not significant

The results suggest that national HEIs and their university status level demonstrated more vital acceptance and practices to TQM. Hence, this study provides practical suggestions for Filipino HEIs to improve their implementation of TQM further. In the framework of this study, four elements have been discovered to spelling variations in the adoption of TQM, including strategic planning, data management, teaching and learning-delivery styles, as well as benchmarking. These criteria have been identified for participating in significant 
colleges in the Philippines. Their significant attention on these issues has contributed to their quality-management structure.

Looking at the context of top management's commitment, as a component of TQM that is favoured by the private colleges in the Philippines, Calvo-Mora et al. (2014) stated that leadership is an essential element in the success of TQM. Therefore, management should demonstrate its dedication via effective resource-allocation, in order to support the fulfilment of all the procedural goals and of the development thereof. Haffer and Kristensen (2010) emphasised that management is liable for the engagement and involvement of all their employees; and, consequently, management must encourage workers to engage in outcomemaking, and to improve their operations.

In summary, the right direction of human capital should influence the appropriate execution and the development of the organization's operations, leading to improved outcomes. Likewise, strategic management should also be developed as a significant topic to be examined by universities on their TQM application. This study has indicated that Private HEIs are innovative and intervention-oriented; and they need to establish a proper balance throughout the strategic planning process. Compared to their public counterparts, Filipino private HEIs feel that profit-making comprises a part of their motivation.

Filipino private colleges were primarily supported by their tuition fees, rather than via government money or charity contributions. As a result, private institutions depend more on customers' (students') experiences in their strategic planning, due to financial differences. Hayhoe et al. (2012) affirmed that the managers in private institutions are, therefore, distinct from their specified-term equivalents in public institutions, given that they often view the organization as their lifetime enterprise; and they, consequently, have a greater sense of purpose. Moreover, strategic planning is an important performance indicator of HEIs, when TQM is taken into consideration (Li, 2012, Mok \& Jiang,2016, Yonezawa et al., 2016).

\section{Conclusion}

This study has examined the implementation of Total Quality Management (TQM), as well as the practices of selected higher education institutions in the Philippines. It has utilized a cross-sectional survey-research approach with a total of 347 respondents. The results have indicated that the participating Filipino HEIs have had a high degree of adoption on the commitment of top management, Teaching and Learning Delivery Modes, campus amenities, system and process management, customer satisfaction, and linkages. In contrast, the HEIs have a modest degree of acceptance in strategic planning and Data Management. A test of the differences indicates that the strong confirmation to top management's commitment and strategic planning, as indicators of TQM, is significantly more evidential to private type HEIs and those placed at the university level, when compared to those of the provincial and national HEIs. 
The findings provide some practical implications to further enhance Filipino HEIs in the advent of the Fourth Industrial Revolution.

\section{Practical Teaching and Learning Implications}

The results of this study indicate numerous implications for the policies and the practices among higher educational institutions in the globe, in general, and the Filipino environment in particular. Firstly, there is a need to enhance further the Filipino institutions' strategic planning and their data-management skills, in order to get the maximum advantages of the Total Quality-Management (TQM) techniques. Secondly, partnerships with private HEIs could facilitate learning more about their management commitment and strategic framework. This is a strong foundation for other Filipino HEIs on which to embark. It was discovered that private HEIs place a high priority on these characteristics.

Thirdly, the universities should become more dynamic and adaptive to changes, in order to cope with the difficulties of Education 4.0 effectively. Fourthly, there is a need for Filipino HEIs to become more flexible and inventive in the following areas: top management's commitment, Teaching, and Learning Delivery Modes, campus amenities, system and process management, customer satisfaction, and connections, in order to become successful. They should be able to assist in creating new ideas to adapt to the ever-changing environment of university education in the Philippines.

\section{Limitations and a Future-Research Direction}

As with any research, this has some constraints and limitations. Future study should, therefore, expand upon this approach, by repeating the procedure across other types of institutions. A sampling approach of responses from a vast number of colleges would decrease any bias in the selection process. The study focuses on the eight aspects of TQM. The development of questions that dive further into the features of all HEIs in consideration could produce more studies. Alternatively, it might be helpful to interview those individuals, who have had this institution in the deciding set; and eventually, they have opted to attend a university. More study is needed, in order to offer a complete explanation that considers the comprehension of the various stakeholders.

\section{References}

Abbas, J. (2020). Impact of total quality management on corporate sustainability through the mediating effect of knowledge management. Journal of Cleaner Production, 244, 118806. https://www.sciencedirect.com/science/article/abs/pii/S0959652619336765

Abdi, H., \& Williams, L. J. (2010). Tukey's honestly significant difference (HSD) test. Encyclopaedia of research design, 3(1), 1-5.

Abu Amuna, Y. M., Al Shobaki, M. J., Abu-Naser, S. S., \& Badwan, J. J. (2017). Understanding Critical Variables for Customer-Relationship Management in Higher Education Institutions from Employees' Perspective. http://dstore.alazhar.edu.ps/xmlui/handle/123456789/407

Aljuhani, A. (2019). Challenges to Successful Total Quality-Management (TQM) Implementation in Saudi Higher Education Institutions. Indiana State University. 
Alzafari, K., \& Kratzer, J. (2019). Challenges of implementing quality in European higher education: an expert perspective. Quality in Higher Education, 25(3), 261-288. https://www.tandfonline.com/doi/abs/10.1080/13538322.2019.1676963

Al-Zoubi, M. T. (2012). Generating benchmarking indicators for employee job satisfaction. Total Quality Management \& Business Excellence, 23(1), 27-44. https://www.tandfonline.com/doi/abs/10.1080/14783363.2011.637780

Aminbeidokhti, A., Jamshidi, L., \& Mohammadi Hoseini, A. (2016). The effect of the total quality management on organizational innovation in higher education mediated by organizational learning. Studies in Higher Education,41(7), 1153-1166. https://www.tandfonline.com/doi/abs/10.1080/03075079.2014.966667

Arcinas, M. M. (2021). A Blockchain Based Framework for Securing Students' Educational Data. Linguistica Antverpiensia, 4475-4484.

Arcinas, M. M., Tolentino, M. P., Lituañas, C. R. A., Cadeliña, J. S., \& Obayashi, Y. (2020). e-Health and Healthy Ageing Among the Participating Countries in JST Sakura Science Exchange Program 2019. Asia-Pacific Social Science Review, 20(2), 149-157.

Arda, O. A., Bayraktar, E., \& Tatoglu, E. (2019). How do integrated quality and environmental management practices affect firms' performance? Mediating roles of quality performance and environmental proactivity. Business Strategy and the Environment, 28(1),

64-78. https://onlinelibrary.wiley.com/doi/abs/10.1002/bse.2190

Baig, S. A., Abrar, M., Ali, A., \& Ahmad, M. (2015). Implementation of TQM on higher education in Pakistan. Quality \& Quantity, 49(1), 51-56. https://link.springer.com/article/10.1007/s11135-013-9973-7

Baptista, B. V., Vasen, F., \& Soto, J. C. V. (2019). Interdisciplinary centres in Latin American Universities: The challenges of institutionalization. Higher Education Policy, 32(3), 461-483. https:/ /link.springer.com/article/10.1057/s41307-018-0092-x

Bouranta, N., Psomas, E. L., \& Pantouvakis, A. (2017). Identifying the critical determinants of TQM and their impact on a company's performance: Evidence from the hotel industry of Greece. The TQM Journal. https://www.emerald.com/insight/content/doi/10.1108/TQM-11-20150142/full/html

Brem, A., Maier, M., \& Wimschneider, C. (2016). Competitive advantage through innovation: the case of Nespresso. European Journal of Innovation Management.

Breslow, N. E., \& Weiss, N. (2018). Multi-Phase Sampling. In Handbook of Statistical Methods for Case-Control Studies (pp. 219-238). Chapman and Hall/CRC.

Bromiley, P., \& Rau, D. (2014). Towards a practice-based view of strategy. Strategic Management Journal, 35(8), 1249-1256. https://onlinelibrary.wiley.com/doi/abs/10.1002/smj.2238

Bromiley, P., \& Rau, D. (2016). Operations' management and the resource-based view: Another view. Journal of Operations Management, 41, 95-106. https://www.sciencedirect.com/science/article/abs/pii/S0272696315000984

Bryman, A. (2006). Integrating quantitative and qualitative research: how is it done?. Qualitative research, 6(1), 97-113. https://journals.sagepub.com/doi/abs/10.1177/1468794106058877

Calvo-Mora, A., Navarro-García, A., \& Periañez-Cristobal, R. (2015). Project to improve knowledge management and key business results through the EFQM excellence model. International Journal of Project Management, 33(8), 1638-1651. https://www.sciencedirect.com/science/article/abs/pii/S0263786315000113

Calvo-Mora, A., Ruiz-Moreno, C., Picón-Berjoyo, A., \& Cauzo-Bottala, L. (2014). Mediation effect of TQM technical factors in excellence management 
systems. Journal of business research, 67(5), 769-774.

https://www.sciencedirect.com/science/article/abs/pii/S0148296313004128

Cardoso, S., Rosa, M. J., \& Stensaker, B. (2016). Why is quality in higher education not achieved? The view of academics. Assessment $\mathcal{E}$ evaluation in higher education, 41(6), 950-965. https://www.tandfonline.com/doi/abs/10.1080/02602938.2015.1052775

Carvalho, T. (2011). Shaping the 'new' academic profession. In Higher Education in Portugal 1974-2009 (pp. 329-352). Springer, Dordrecht. https://link.springer.com/chapter/10.1007/978-94-007-2135-7_14

Chang, S. J., Hsiao, H. C., Huang, L. H., \& Chang, H. (2011). Taiwan quality indicator project and hospital productivity growth. Omega, 39(1), 14-22. https:// www.sciencedirect.com/science/article/ pii/S0305048310000071

Charernnit, K., Alhourani, A. Q., Arcinas, M. M., Velasco, L. G., \& Alhourani, A. Q. Cognitive and Attitudinal Effects of Jigsaw Technique as a CollaborativeLearning Strategy in Literature Teaching in the Philippines.

Chen, I. S., Chen, J. K., \& Padro, F. F. (2017). Critical quality indicators of higher education. Total Quality Management \& Business Excellence, 28(1-2), 130-146 https://www.tandfonline.com/doi/abs/10.1080/14783363.2015.1050178

Chen, R., Lee, Y. D., \& Wang, C. H. (2020). Total quality management and sustainable competitive advantage: serial mediation of transformational leadership and executive ability. Total Quality Management \& Business Excellence, 31(5-6), 451-468. https://www.tandfonline.com/doi/abs/10.1080/14783363.2018.1476132

Cho, Y. S., Jung, J. Y., \& Linderman, K. (2017). The QM evolution: Behavioral quality management as a firm's strategic resource. International Journal of Production Economics, 191, 233-249. https://www.sciencedirect.com/science/article/abs/pii/S0925527317301391

Clay-Williams, R., Taylor, N., Ting, H. P., Winata, T., Arnolda, G., Austin, E., \& Braithwaite, J. (2020). The relationships between quality-management systems, safety culture and leadership and patient outcomes in Australian Emergency Departments. International Journal for Quality in Health Care, 32(Supplement_1), 43-51. https://doi.org/10.1093/intqhe/mzz105

Corredor, P., \& Goñi, S. (2011). TQM and performance: Is the relationship so obvious? Journal of Business Research, 64(8), 830-838. https://doi.org/10.1016/j.jbusres.2010.10.002

Costandi, S., Hamdan, A., Alareeni, B., \& Hassan, A. (2019). Educational governance and challenges to universities in the Arabian Gulf region. Educational Philosophy and Theory, 51(1), 70-86. https://doi.org/10.1080/00131857.2018.1434621

Coughlan, M., Cronin, P., \& Ryan, F. (2007). Step-by-step guide to critiquing research. Part 1: quantitative research. British journal of nursing, 16(11), 658-663. https://doi.org/10.12968/bjon.2007.16.11.23681

Cudney, E. A., Venuthurumilli, S. S. J., Materla, T., \& Antony, J. (2020). Systematic review of Lean and Six Sigma approaches in higher education. Total Quality Management $\mathcal{E} \quad$ Business Excellence, 31(3-4), 231-244. https:// doi.org/10.1080/14783363.2017.1422977

Cuenca-Amigo, M., \& Makua, A. (2017). Audience development: a cross-national comparison. Academia Revista Latinoamericana de Administración. https://www.emerald.com/insight/content/doi/10.1108/ARLA-06-20150155/full/html

De Souza, R., Parveen, R., Chupradit, S., Velasco, L. G., Arcinas, M., Tabuena, A. C., ... \& Ventayen, R. J. M. (2021). Language Teachers' Pedagogical Orientations in Integrating Technology in the Online Classroom: Its Effect on Students' 
Motivation and Engagement. Turkish Journal of Computer and Mathematics Education, 12.

https://turcomat.org/index.php/turkbilmat/article/view/5268

De Vincenzi, A., Garau, A., \& Guaglianone, A. (2018). Has the quality of teaching and learning processes improved, as a result of the implementation of quality assurance coordinated by the state? Quality in Higher education, 24(1), 55-65. https:// doi.org/10.1080/13538322.2018.1426382

Delery, J. E., \& Roumpi, D. (2017). Strategic human resource management, human capital and competitive advantage: is the field going in circles?. Human Resource Management Journal, 27(1), 1-21. https:// doi.org/10.1111/1748-8583.12137

Deshpande, M. (2020). Lean Model of Quality Management in Higher Education. In Quality Management Implementation in Higher Education: Practices, Models, and Case Studies (pp. 153-173). IGI Global.

Dias, D. (2015). Has massification of higher education led to more equity? Clues to a reflection on Portuguese education arena. International Journal of Inclusive Education, 19(2), 103-120. https:// doi.org/10.1080/13603116.2013.788221

Ding, H., Fu, Y., Zheng, L., \& Yan, Z. (2019). Determinants of the competitive advantage of dairy- supply chains: Evidence from the Chinese dairy industry. International Journal of Production Economics, 209, 360-373. https://doi.org/10.1016/j.ijpe.2018.02.013

Do, Q. T., Pham, H. T., \& Nguyen, K. D. (2017). Quality assurance in the Vietnamese higher education: A top-down approach and compliance-driven QA. In The rise of quality assurance in Asian higher education (pp. 191-207). Chandos Publishing. https://doi.org/10.1016/B978-0-08-100553-8.00005-7

Ellahi, R. M., Khan, M. U. A., \& Shah, A. (2019). Redesigning Curriculum in line with Industry 4.0. Procedia computer science, 151, 699-708. https://doi.org/10.1016/j.procs.2019.04.093

Ferdousi, F., Baird, K., Munir, R., \& Su, S. (2018). Associations between organisational factors, TQM and competitive advantage: Evidence from an emerging economy. Benchmarking: An International Journal.

Florkowski, W. J., \& Jiang, Q. (2017). Constraints in Implementing Quality-Assurance Programs in Food Manufacturing Firms in Shanghai, China. Management, Enterprise and Benchmarking in the 21st Century, 66. https://kgk.uniobuda.hu/sites/default/files/06_Florkowski_Jiang.pdf

Fundin, A., Bergquist, B., Eriksson, H., \& Gremyr, I. (2018). Challenges and propositions for research in quality management. International Journal of Production Economics, 199, 125-137. https://doi.org/10.1016/j.ijpe.2018.02.020

Grudzien, Ł., \& Hamrol, A. (2016). Information quality in design process documentation of quality management systems. International Journal of Information Management, 36(4), 599-606. https:/ / doi.org/10.1016/j.ijinfomgt.2016.03.011

Haffer, R., \& Kristensen, K. (2010). People management as indicator of business excellence: the Polish and Danish perspectives. The TQM Journal.

Hayhoe, R., Li, J., Lin, J., \& Zha, Q. (2012). Portraits of 21st Century Chinese Universities:: In the Move to Mass Higher Education (Vol. 30). Springer Science \& Business Media.

Helleno, A. L., de Moraes, A. J. I., \& Simon, A. T. (2017). Integrating sustainability indicators and Lean Manufacturing to assess manufacturing processes: Application case studies in Brazilian industry. Journal of cleaner production, 153, 405-416. https:// doi.org/10.1016/j.jclepro.2016.12.072

Hou, A. Y. C., Hill, C., Chen, K. H. J., \& Tsai, S. (2018). A comparative study of international branch campuses in Malaysia, Singapore, China, and South Korea: Regulation, 
governance, and quality assurance. Asia Pacific Education Review, 19(4), 543-555. https:/ /link.springer.com/article/10.1007/s12564-018-9550-9

Hu, J., Liu, H., Chen, Y., \& Qin, J. (2018). Strategic planning and the stratification of Chinese higher education institutions. International Journal of Educational Development, 63, 36-43. https://doi.org/10.1016/j.ijedudev.2017.03.003

Johansson, P. E., \& Wallo, A. (2019). Exploring the work and competence of interactive researchers. Journal of Manufacturing Technology Management.

https://www.emerald.com/insight/content/doi/10.1108/JMTM-09-20180307/full/html

Kasiri, L. A., Cheng, K. T. G., Sambasivan, M., \& Sidin, S. M. (2017). Integration of standardization and customization: Impact on service quality, customer satisfaction, and loyalty. Journal of Retailing and Consumer Services, 35, 91-97. https:// doi.org/10.1016/j.jretconser.2016.11.007

Kern Pipan, K., Gomišček, B., \& Kljajić, M. (2014). Slovenian national excellence award and total quality management deployment in Slovenian companies. Total quality management $\mathcal{E} \quad$ business excellence, 25(7-8), 750-762. https://doi.org/10.1080/14783363.2014.904569

Khan, M. N., Malik, S. A., \& Janjua, S. Y. (2019). Total Quality-Management practices and work-related outcomes: A case study of higher education institutions in Pakistan. International Journal of Quality \& Reliability Management.

Kong, D., Feng, Q., Zhou, Y., \& Xue, L. (2016). Local implementation for greenmanufacturing technology diffusion policy in China: from the user firms' perspectives. Journal of cleaner production, 129, 113-124. https://doi.org/10.1016/j.jclepro.2016.04.112

Kumar, T. P., Priyadarsini, M. K., \& Ranganathan, B. (2018). A Study on Impact of Total Quality Management on Performance of Self-Financing Engineering Institutions. International Journal on Global Business Management $\mathcal{E}$ Research, 7(2), 12-22.

https:// www.proquest.com/openview/0b92c8d948fae2358815cde1ac8390d7/1? pq-origsite $=$ gscholar\&cbl=2032289

Lee, V. H., Ooi, K. B., Tan, B. I., \& Chong, A. Y. L. (2010). A structural analysis of the relationship between TQM practices and product innovation. Asian Journal of Technology Innovation, 18(1),

73-96. https://doi.org/10.1080/19761597.2010.9668683

Levy, G. D., \& Ronco, S. L. (2012). How benchmarking and higher education came together. New Directions for Institutional Research, 156, 5-13. https://eric.ed.gov/?id=EJ988380

Li, D., Zhao, Y., Zhang, L., Chen, X., \& Cao, C. (2018). Impact of quality management on green innovation. Journal of cleaner production, 170, 462-470. https://doi.org/10.1016/j.jclepro.2017.09.158

Li, J. (2012). World-class higher education and the emerging Chinese model of the university. Prospects, 42(3),

319-339. https://link.springer.com/article/10.1007\%2Fs11125-012-9241-y

Liao, L., Lin, T. P., \& Zhang, Y. (2018). Corporate board and corporate social responsibility assurance: Evidence from China. Journal of Business Ethics, 150(1), 211-225. https://link.springer.com/article/10.1007/s10551-016-3176-9

Liu, S., \& Liu, J. (2017). Quality assurance in Chinese higher education. In The Rise of Quality Assurance in Asian Higher Education (pp. 15-33). Chandos Publishing. https://doi.org/10.1016/B978-0-08-100553-8.00001-X

Ma, G. (2019). The Strategic Orientation of High-Quality Development of Higher Continuing Education in China. In Shaping the Future of Education, Communication 
and Technology (pp. 25-37). Springer, Singapore.

https://link.springer.com/chapter/10.1007/978-981-13-6681-9_3

Magulod, Jr, G. C. (2017). Factors of school effectiveness and performance of selected public and private elementary schools: implications on educational planning in the Philippines. Asia Pacific Journal of Multidisciplinary Research, 5(1), 73-83.

Magulod Jr, G. C. (2019). Learning styles, study habits and academic performance of Filipino University students in applied science courses: Implications for instruction. JOTSE: Journal of Technology and Science Education, 9(2), 184-198. http://hdl.handle.net/2117/134350

Mahdi, O. R., Nassar, I. A., \& Almsafir, M. K. (2019). Knowledge-management processes and sustainable competitive advantage: An empirical examination in private universities. Journal of Business Research, 94, 320-334.

Manatos, M. J., Sarrico, C. S., \& Rosa, M. J. (2017). The integration of quality management in higher education institutions: a systematic literature review. Total Quality Management $\mathcal{E} \quad$ Business Excellence, 28(1-2), 159-175. https://doi.org/10.1080/14783363.2015.1050180

Martin, J., Elg, M., Gremyr, I., \& Wallo, A. (2021). Towards a quality-management competence framework: exploring needed competencies in quality management. Total Quality Management \& Business Excellence, 32(3-4), 359-378. https://doi.org/10.1080/14783363.2019.1576516

Martínez-Caro, E., Cegarra-Navarro, J. G., \& Cepeda-Carrión, G. (2015). An application of the performance-evaluation model for e-learning quality in higher education. Total Quality Management \& Business Excellence, 26(5-6), 632-647. https://doi.org/10.1080/14783363.2013.867607

Meesala, A., \& Paul, J. (2018). Service quality, consumer satisfaction and loyalty in hospitals: Thinking for the future. Journal of Retailing and Consumer Services, 40, 261-269. https://doi.org/10.1016/j.jretconser.2016.10.011

Mehralian, G., Rasekh, H. R., Akhavan, P., \& Ghatari, A. R. (2013). Prioritization of intellectual capital indicators in knowledge-based industries: Evidence from pharmaceutical industry. International Journal of Information Management, 33(1), 209-216. https://doi.org/10.1016/j.ijinfomgt.2012.10.002

Mendes, L., \& Dias, D. (2018). Corporate social responsibility and total quality management: the stakeholders' value-creation debate revisited. Entrepreneurial, Innovative and Sustainable Ecosystems, 255-283. https://link.springer.com/chapter/10.1007/978-3-319-71014-3_13

Mok, K. H., \& Jiang, J. (2016). Massification of higher education: Challenges for admissions and graduate employment in China. In Managing international connectivity, diversity of learning and changing labour markets (pp. 219-243). Springer, Singapore. https://link.springer.com/chapter/10.1007/978-981-10-1736-0_13

Moldovan, L. (2012). Integration of strategic management and quality assurance in the Romanian higher education. Procedia-Social and Behavioral Sciences, 58, 14581465. https://doi.org/10.1016/j.sbspro.2012.09.1132

Moreno-Luzon, M. D., Gil-Marques, M., \& Valls-Pasola, J. (2013). TQM, innovation and the role of cultural change. Industrial Management $\mathcal{E}$ Data Systems.

https://www.emerald.com/insight/content/doi/10.1108/IMDS-02-20130075/full/html

Murmura, F., Casolani, N., \& Bravi, L. (2016). Seven keys for implementing the selfevaluation, periodic evaluation and accreditation (AVA) method, to improve quality and student satisfaction in the Italian higher education system. Quality in Higher education, 22(2), 167-179. https:/ / doi.org/10.1080/13538322.2016.1220695

Nardi, P. M. (2018). Doing survey research: A guide to quantitative methods. Routledge. 
Nuncio, R. V., Arcinas, M. M., Lucas, R. I. G., Alontaga, J. V. Q., Neri, S. G. T., \& Carpena, J. M. (2020). An E-learning outreach program for public schools: Findings and lessons learned based on a pilot program in Makati City and Cabuyao City, Laguna, Philippines. Evaluation and Program Planning, 82, 101846. https://doi.org/10.1016/j.evalprogplan.2020.101846

Nurcahyo, R., Apriliani, F., Muslim, E., \& Wibowo, A. D. (2019). The analysis of the implementation of the 5-S principles integrated with ISO 9001 requirements at higher education level. Sage Open, 9(3), 2158244019870773.

Nyadzayo, M. W., \& Khajehzadeh, S. (2016). The antecedents of customer loyalty: A moderated mediation model of customer relationship management quality and brand image. Journal of retailing and consumer services, 30, 262-270. https:// doi.org/10.1016/j.jretconser.2016.02.002

O'Neill, P., Sohal, A., \& Teng, C. W. (2016). Quality-management approaches and their impact on firms' financial performance-An Australian study. International Journal of Production Economics, 171, 381-393. https:// doi.org/10.1016/j.ijpe.2015.07.015

Olcay, G. A., \& Bulu, M. (2017). Is measuring the knowledge creation of universities possible?: A review of university rankings. Technological Forecasting and Social Change, 123, 153-160. https:// doi.org/10.1016/j.techfore.2016.03.029

Ooi, K. B., Lee, V. H., Chong, A. Y. L., \& Lin, B. (2013). Does TQM improve employees' quality of work life? Empirical evidence from Malaysia's manufacturing $\begin{array}{llll}\text { firms. Production Planning } \quad \mathcal{E} \quad \text { Control, 24(1), } & \text { 72-89. }\end{array}$ https://doi.org/10.1080/09537287.2011.599344

Pennock, L., Jones, G. A., Leclerc, J. M., \& Li, S. X. (2015). Assessing the role and structure of academic senates in Canadian universities, 2000-2012. Higher Education, 70(3), 503-518. https://link.springer.com/article/10.1007/s10734-014-9852-8

Phan, A. C., Abdallah, A. B., \& Matsui, Y. (2011). Quality-management practices and competitive performance: Empirical evidence from Japanese manufacturing companies. International Journal of Production Economics, 133(2), 518-529. https://doi.org/10.1016/j.ijpe.2011.01.024

Psomas, E., \& Antony, J. (2017). Total quality-management elements and results in higher education institutions: The Greek case. Quality Assurance in Education. https:// www.emerald.com/insight/content/doi/10.1108/QAE-08-20150033/full/html

Rahimnia, F., \& Kargozar, N. (2016). Objectives' priority in university strategy map for resource allocation. Benchmarking: An International Journal. https://www.emerald.com/insight/content/doi/10.1108/BIJ-09-20130094/full/html

Rampa, S. H. (2010). A customised total quality-management framework for schools. Africa Education Review, 7(1), 199-217. https:// doi.org/10.1080/18146627.2010.490013

Rocha, I. C. N., \& Arcinas, M. M. (2020). Quality of Life of Filipino Caregivers of Children in Need of Special Protection: Correlations with their Role Overload and Role Distress. Journal of Caring Sciences, 9(4), 173. https://www.ncbi.nlm.nih.gov/pmc/articles/PMC7770392/

Roldán, J. L., Leal-Rodríguez, A. L., \& Leal, A. G. (2012). The influence of organisational culture on the Total Quality Management programme performance. Investigaciones Europeas de Dirección y Economía de la Empresa, 18(3), 183-189. https://doi.org/10.1016/j.iedee.2012.05.005

Rolstadås, A., Henriksen, B., \& O'Sullivan, D. (2012). Manufacturing outsourcing: A knowledge perspective. Springer Science \& Business Media.

Ross, J. E. (2017). Total quality management: Text, cases, and readings. Routledge. 
Ruben, B. D. (2018). The quality approach in higher education: Context and concepts for change. In Quality in higher education (pp. 1-34). Routledge.

Sabarre, J., Villareal, P. L. H., \& Arcinas, M. (2021). Filipino Adolescents' Experiences of Abusive Parent-Child Relationship in Low Socio-economic Status Families. Journal of Humanities and Social Sciences Studies, 3(4), 06-18. https://alkindipublisher.com/index.php/jhsss/article/view/1511

Sahney, S. (2016). Use of multiple methodologies for developing a customer-oriented model of total quality management in higher education. International journal of educational https://www.emerald.com/insight/content/doi/10.1108/IJEM-09-20140126/full/html

Saiz-Alvarez, J. M. (2020). Quality-Management Principles' Application to Higher Educational Institutions. In Quality-Management Principles and Policies in Higher Education (pp. 1-22). IGI Global.

Shams, S. R., \& Belyaeva, Z. (2019). Quality assurance driving factors as antecedents of knowledge management: A stakeholder-focussed perspective in higher education. Journal of the Knowledge Economy, 10(2), 423-436. https://link.springer.com/article/10.1007/s13132-017-0472-2

Shroff, N. (2019). TQM indicators implemented by teachers of the primary school. In Logistics, Supply Chain and Financial Predictive Analytics (pp. 243-254). Springer, Singapore. https://link.springer.com/chapter/10.1007/978-981-13-0872-7_19

Song, J. (2018). Creating world-class universities in China: Strategies and impacts at a renowned research university. Higher Education, 75(4), 729-742. https://link.springer.com/article/10.1007/s10734-017-0167-4

Stensaker, B., Langfeldt, L., Harvey, L., Huisman, J., \& Westerheijden, D. (2011). An indepth study on the impact of external quality assurance. Assessment $\mathcal{E}$ Evaluation in Higher Education, 36(4), 465-478. https://doi.org/10.1080/02602930903432074

Suarez, E., Calvo-Mora, A., \& Roldán, J. L. (2016). The role of strategic planning in excellence management systems. European journal of operational research, 248(2), 532-542. https://doi.org/10.1016/j.ejor.2015.07.008

Sweis, R. J., Al-Ghawi, H. J., AlSaleh, N. A. A., Zu'bi, M. F., \& Obeidat, B. Y. (2015). Benchmarking of TQM: the case of the Hikma Pharmaceutical company. Benchmarking: An International Journal. https://www.emerald.com/insight/content/doi/10.1108/BIJ-05-20130059/full/html

Sweis, R. J., Saleh, F. I. M., Dahiyat, S. E., Sweis, N. J., Saleh, R. A., \& Diab, H. (2016). Benchmarking of TQM practices in INGOs: a literature review. Benchmarking: An International Journal.

Tasopoulou, K., \& Tsiotras, G. (2017). Benchmarking towards excellence in higher education. Benchmarking: An International Journal.

Taylor, P., Saheb, R., \& Howse, E. (2019). Creating healthier graduates, campuses and communities: Why Australia needs to invest in health promoting universities. Health Promotion Journal of Australia, 30(2), 285-289.

https://onlinelibrary.wiley.com/doi/abs/10.1002/hpja.175

Teoman, S., \& Ulengin, F. (2018). The impact of management leadership on quality performance throughout a supply chain: an empirical study. Total Quality Management $\mathcal{E} \quad$ Business Excellence, 29(11-12), 1427-1451. https:// doi.org/10.1080/14783363.2016.1266244

Tiwari, K., \& Kumar Sharma, A. (2017). Transactional leadership in total quality management. Internafional Journal of Engineering Technology Science and Research, 4(3), 97-100. 
Tolentino, M. P., \& Arcinas, M. M. (2018). Social capital of left-behind children: Determinants and association with school performance. Asia-Pacific Social Science Review, 18(2), 16-33.

Valmohammadi, C., \& Roshanzamir, S. (2015). The guidelines of improvement: Relations among organizational culture, TQM and performance. International Journal of Production Economics, 164, 167-178. https:/ / doi.org/10.1016/j.ijpe.2014.12.028

Vouzas, F., \& Psychogios, A. G. (2007). Assessing managers' awareness of TQM. The TQM magazine.

Wang, N. (2019). How an organisation responds to multiple institutional logics: integrating UK and Chinese quality assurance systems in one university. The University of Liverpool (United Kingdom).

Wen, W., Hu, D., \& Hao, J. (2018). International students' experiences in China: Does the planned reverse mobility work. International Journal of Educational Development, 61, 204-212.

Wilson, V. (2016). Research methods: sampling. Evidence-Based Library and Information Practice, 11(1 (S)), 69-71.

Yaakub, K. B., \& Samsudin, N. (2019, April). The Development of Measurement Instruments for Total Quality-Management Practices in Higher Education Institutions. In 8th UPI-UPSI International Conference 2018 (UPI-UPSI 2018). Atlantis Press.

Yan, X., Zhang, W., Wang, H., Jia, L., Hou, Y., Xu, T., ... \& Wang, Y. (2019, March). Construction of the Quality-Assurance System for Collaborative Education of Schools and Enterprises Cooperation in Local Universities. In 2018 8th International Conference on Education and Management (ICEM 2018). Atlantis Press.

Yonezawa, A., Horta, H., \& Osawa, A. (2016). Mobility, formation and development of the academic profession in science, technology, engineering and mathematics in East and South-East Asia. Comparative Education, 52(1), 44-61.

Yu, G. J., Park, M., \& Hong, K. H. (2020). A strategic perspective on total quality management. Total Quality Management \& Business Excellence, 31(1-2), 68-81.

Yusr, M. M., Mokhtar, S. S. M., Othman, A. R., \& Sulaiman, Y. (2017). Does interaction between TQM practices and knowledge-management processes enhance the innovation performance? International Journal of Quality $\mathcal{E}$ Reliability Management. 